Отримано: 23 травня 2018 р.

Прорецеензовано: 29 травня 2018 р.

Прийнято до друку: 01 червня 2018 р. e-mail: schwab2004@ukr.net
Швабій К. І., Задорожня Л. А. Міжнародна практика оцінювання податкового розриву з персонального прибуткового податку. Наукові записки Національного університету «Острозька академія». Серія «Економіка» : науковий журнал. Острог : Видво НаУОА, червень 2018. № 9(37). С. 174-178.

DOI: $10.25264 / 2311-5149-2018-9(37)-174-178$

УДК: 336.226 .11

Швабій Костянтин Іванович,

JEL-класифікачія: $H 24$

доктор економічних наук, професор, директор ННІ економіки, оподаткування та митної справи НУДФСУ

Задорожня Ліна Адамівна,

кандидат економічних наук, старший науковий співробітник

Науково-дослідного інституту фіскальної політики НУДФСУ

\title{
МІЖНАРОДНА ПРАКТИКА ОЦІНЮВАННЯ ПОДАТКОВОГО РОЗРИВУ З ПЕРСОНАЛЬНОГО ПРИБУТКОВОГО ПОДАТКУ
}

У статті проаналізовано міжнародну практику оцінки податкового розриву з персонального прибуткового податку, зокрема в Австралії, Канаді, Сполученому Королівстві, Сполучених Штатах Америки та Швеції. Визначено загальне декларування доходів $і$ звітування третіх осіб як основні причини щодо малого розміру податкового розриву із трудових доходів у розвинених державах. Запропоновано підхід щчодо оцінювання податкового розриву із податку на доходи фізичних осіб в Україні, який трунтується на використанні даних щодо доходів домогосподарств та окреслено перспективність проведення досліджень податкового розриву на постійній основі.

Ключові слова: податковий розрив, податок на доходи фізичних осіб, адміністрування податків, трудовий дохід, податкова культура.

\section{Швабий Константин Иванович,}

доктор экономических наук, профессор, директор НИИ экономики, налогообложения и таможенного дела НУГФСУ

Задорожняя Лина Адамовна,

кандидат экономических наук, стариий научный сотрудник

Научно-исследовательского института фискальной политики НУГФСУ

\section{МЕЖДУНАРОДНАЯ ПРАКТИКА ОЦЕНКИ НАЛОГОВОГО РАЗРЫВА С ПЕРСОНАЛЬНОГО ПОДОХОДНОГО НАЛОГА}

В статье проанализировано международную практику оченки налогового разрыва с персонального подоходного налога, в частности в Австралии, Канаде, Соединенном Королевстве, Соединенных Штатах Америки и Швеции. Всеобщее декларирование доходов и отчетность третьих лии определены в качестве основных причин малого размера налогового разрыва с трудовых доходов в развитых государствах. Предложен подход к оценке налогового разрыва по налогу на доходы физических лии в Украине, основанный на использовании данных о доходах домохозяйств и обозначено перспективность проведения исследований налогового разрыва на постоянной основе.

Ключевые слова: налоговый разрыв, налог на доходы физических лии, администрирования налогов, трудовой доход, налоговая культура.

\section{Kostyantyn Shvabii,}

Dr. in Economics, professor, director of Educational and Research Institute of Taxation, Economy and Customs, NUSFSU

\section{Lina Zadorozhnia,}

Ph. D., senior researcher, Research Institute of Fiscal Policy of NUSFSU

\section{INTERNATIONAL PRACTICE OF TAX GAP ASSESSMENT FROM PERSONAL INCOME TAX}

The article deals with the international practice of personal income tax gap assessment, in particular in Australia, Canada, the United Kingdom, the United States of America and Sweden. The compulsory individual incomes declaration and third party reporting are identified as the main reasons for the small size of the employment income tax gap in developed countries. The approach to assessing the personal income tax gap in Ukraine, based on the use of household income data, is outlined as well as the prospects of conducting tax gap research on a regular basis.

Key words: tax gap, personal income tax, administration of taxes, employment income, tax culture.

Постановка проблеми. У ряді розвинених держав світу для оцінки ефективності функціонування системи оподаткування використовується показник податкового розриву (tax gap, далі - ПР). Його дина- 
міка свідчить про ефективність процесів адміністрування, слугує важливим аналітичним інструментом підтримки процесу прийняття рішень у сфері податкової політики держави. Також його можуть розглядати як похідний показник від рівня податкової культури, тобто вищий рівень податкової культури прямо пов' язаний із малим податковим розривом. За своєю природою він є інтегральним показником. ПР дорівнює різниці між податковими надходженням отриманими від усіх платників податків, що сплачені відповідно до чинного законодавства вчасно і в повному обсязі, та фактично отриманими податковими надходженнями. Проте водночас він також є й комплексним, оскільки для його остаточного обчислення необхідно провести значні проміжні підрахунки, оцінити та розрахувати під час велику кількість необхідних додаткових показників і коефіцієнтів. Із методологічного погляду ПР можна оцінити на макрорівні або на мікрорівні. Обидва підходи мають як свої недоліки, так і переваги. Його також можна оцінити за окремим податком або за всіма податками відразу.

Аналіз останніх досліджень і публікацій. Масштабність показника ПР дозволяє сприймати його як такий, що свідчить про ефективність податкової системи загалом. Водночас він $є$ інформативним у контексті чіткості податкової політики та її сприйняття суспільством, легкості тлумачення законів та ефективності роботи контролюючих органів [9, с. 617]. Незважаючи на те, що ПР у розрізі бюджетоутворювальних податків оцінюється податковими службами в 56 державах, але лише 13 із них оприлюднюють ці дані $[14$, с. 132]. Питання оцінювання ПР досліджували як вітчизняні, так і зарубіжні вчені. Зокрема, А. Вдовиченко, А. Зубрицький розглянули концепцію ПР як індикатора ефективності діяльності податкових адміністрацій [1], а М. Фільо - сутність ПР [5]. Н. Геммен, Дж. Хасселдін дослідили методологічні засади оцінювання ПР у США й Австралії, наголосивши, що, незважаючи на застосування передових методик розрахунків, отримувані дані залишаються дискусійними [8]. Н. Воррен, Ж. Макманус наголосили на важливості врахування ПР під час реформування податкової системи [18]. С. Гамільтон комплексно оцінив на переваги і недоліки ПР, а також вказав на необхідність здійснення витрат на оцінювання ПР і вигод від цього [9].

Метою роботи є дослідження міжнародного досвіду оцінювання ПР із персонального прибуткового податку, а також можливостей застосування наявних підходів до оцінки ПР із податку на доходи фізичних осіб в України.

Виклад основного матеріалу. Оцінювання ефективності адміністрування податків відбувається за рядом показників, проте одним із найперспективніших із огляду на комплексний характер є ПР. Він може розраховуватися як на щорічній основі (у Сполученому Королівстві), так і з певною періодичністю 2-5 роки, як-от у Австралії, Данії, Канаді, США, Швеції. Відповідно до вказаного методології містять деякі відмінності, що відображається на розмірі визначеного ПР. Зокрема, метод «зверху вниз» найчастіше застосовують до ПДВ, тоді як метод «знизу вверх» використовують для оцінки доходів фізичних осіб, та малих і середніх підприємств, базуючись на даних випадкового аудиту. Також метод «знизу вверх» iз використанням експертних суджень базується на операційному (тобто не випадковому аудиті) i його застосовують до великих корпорацій і фізичних осіб із високими доходами. Включення показників «невиявлення порушень», «доходу від злочинної діяльності», а також ступінь використання методів оцінки «зверху вниз», «знизу вверх» та інші суттєво впливають на отримувані дані [9, с. 618-620].

Австралія є однією із держав, у якій ПР розраховують на постійній основі. Для оцінки рівня недотримання податкового законодавства, досліджуються процедури реєстрації, подачі звітності та сплати податкових зобов'язань до бюджету (водночас штрафи та пеню не враховують до оцінки ПР). ПР розглядають через призму валового розриву (різниці між добровільно визначеними зобов'язаннями і теоретичного рівня податкових зобов'язань при повному слідуванні податкових зобов'язань) та чистого розриву (різниця між задекларованими податковими зобов'язаннями і сумою, що могла б бути зібраною, у разі повного дотримання норм податкового законодавства). Відповідно до методологічних пояснень, використовують методи «зверху вниз» (залучення агрегованих даних із зовнішніх джерел, як-от із Австралійського бюро статистики), а також «знизу вверх» (передбачає аналіз внутрішніх даних із податкових декларацій та даних перевірок, після чого отримані дані екстраполюються на все населення). Під час оцінки ПР із утримань із заробітних плат і пенсійних гарантій використовують метод «зверху вниз», що забезпечує середній рівень надійності. Для 2014-2015 рр. фіскального року ПР із утримань із заробітної плати становив 3,1 млрд дол., тобто рівень слідування податкового законодавства становить 95\%. На такому ж рівні й слідування вимогам пенсійного забезпечення, а розрив був оцінений у розмірі 2,85 млрд дол. [6].

ПР із утримань із заробітної плати визначають як різницю між податками, що повинні бути утримані роботодавцями із трудових доходів відповідно до законодавства та фактичною сумою ПДФО, що була утримана та сплачена до бюджету за фінансовий рік. Обов'язок здійснення утримань регламентується законом «Про адміністрування податків» (1953р.), згідно з яким роботодавці повинні зареєструватися в установленому порядку та здійснювати утримування. Варто відзначити, що станом на 2014-2015 рр. фінансовий рік у Австралії було зареєстровано близько 880 тис. роботодавців та утримано 166 млрд дол. iз доходів фізичних осіб (таблиця 1). Наявність ПР із утримання податків із заробітної плати пов'язано 
із неповним звітуванням про обсяг заробітних плат, звітування або перерахування податку поза межами установлених строків, хибне трактування працівників як підрядників. Податкова служба Австралії вживає ряд заходів для зменшення ПР: надаючи онлайн-допомогу для заохочення добровільного слідування податкового законодавства, демонструючи свої інструменти та калькулятори у процесі взаємодії із клієнтами, проводячи інформаційні сесії через семінари, вебінари та під час співпраці із професійними об'єднаннями, асоціаціями, що дає позитивні результати, оскільки ПР має тенденцію до зменшення [12].

Таблиця 1

Податковий розрив із утримань із заробітної плати у вигляді персонального прибуткового податку в Австралії, млн дол.

\begin{tabular}{|c|c|c|c|c|c|}
\hline Розрив & \begin{tabular}{|c|}
$\begin{array}{c}2009-2010 \\
\text { фінансовий } \\
\text { рік }\end{array}$ \\
\end{tabular} & $\begin{array}{c}\begin{array}{c}2010-2011 \\
\text { фінансовий } \\
\text { рік }\end{array} \\
\end{array}$ & $\begin{array}{c}20112012 \\
\text { фінансовий } \\
\text { рік } \\
\end{array}$ & \begin{tabular}{|c|}
20122013 \\
$\begin{array}{c}\text { фінансовий } \\
\text { рік }\end{array}$ \\
\end{tabular} & $\begin{array}{c}20132014 \\
\text { фінансовий } \\
\text { рік } \\
\end{array}$ \\
\hline Теоретичний рівень утримань & 120757 & 131992 & 145341 & 151014 & 157982 \\
\hline Вплив тіньової економіки & 1519 & 1660 & 1824 & 1888 & 1974 \\
\hline Оцінений теоретичний рівень утримань & 122277 & 133652 & 147165 & 152901 & 159957 \\
\hline $\begin{array}{l}\text { Утримання, про які відзвітовано і які спла- } \\
\text { чені }\end{array}$ & 117741 & 129275 & 142015 & 149281 & 156409 \\
\hline Валовий розрив & 5420 & 6193 & 7112 & 5963 & 5718 \\
\hline Коригування & 884 & 912 & 1050 & 1488 & 1357 \\
\hline Чистий розрив & 4536 & 5281 & 6062 & 4475 & 4360 \\
\hline Валовий розрив, \% & $4,4 \%$ & $4,6 \%$ & $4,8 \%$ & $3,9 \%$ & $3,6 \%$ \\
\hline Чистий розрив, \% & $3,7 \%$ & $4,0 \%$ & $4,1 \%$ & $2,9 \%$ & $2,7 \%$ \\
\hline
\end{tabular}

Джерело: [12].

У контексті адміністрування податків і зборів із заробітної плати в Австралії ПР розраховується і для пенсійних внесків, які сплачують роботодавці за ставкою 9,5\% 31 липня 2014 р. (із 1 липня 2002 р. ставка становила $9 \%$ і зросла до 9,25\%) з огляду на його стратегічне значення для забезпечення стабільності і гарантованості пенсійного забезпечення для найманих працівників. Роль Податкової служби полягає в адмініструванні внесків на пенсійне страхування, а також стягнення штрафів за порушення (штраф застосовують у вигляді номінальної відсоткової ставки й адміністративного збору, що застосовують до недостачі). Тим не менше, $95 \%$ із 880 тис. роботодавців в Австралії добровільно в повному обсязі сплачують пенсійні внески (кількість найманих працівників становила 11,7 млн осіб), сплативши 51,51 млрд дол. пенсійних внесків у 2014-2015 рр. Приблизно 20 тис. звітів про підозри про несплачені пенсійні внески отримується Податковою службою щорічно, більшість із яких від малого бізнесу, що надає послуги із здачі житла, харчування, чи веде діяльність у сфері будівництва та роздрібної торгівлі [13].

Визначення ПР із внесків на пенсійне страхування здійснюється із використанням статистичних даних Австралійського бюро статистики для визначення розміру заробітних плат, але здійснюються коригування із врахуванням сум, на які не нараховують пенсійні внески (тобто менше 450 дол. протягом місяця), сум, що не розглядають як звичайний дохід (наприклад, доплати за понаднормову роботу) та суми, пов'язані із функціонуванням тіньової економіки (не задекларовані виплати працівникам і співробітникам, що беруть участь у фіктивних схемах). Далі до отриманого фонду заробітної плати застосовують ставку 9,5\% (для пенсійного страхування), отриману суму трактують як оцінений теоретичний рівень зі сплати внесків на пенсійне страхування, який склав 54,78 млрд дол. у 2014-2015 фінансовому році (тоді як сплачені внески на пенсійне страхування становили 51,51 млрд дол.), тобто валовий ПР становив 3,26 млрд дол. Урахування прямого впливу на дотримання вимог законодавства (наприклад, перевірки) призвели до 414 млн дол. донарахувань, тобто чистий ПР становив 2,85 млрд дол. у 2014-2015 фінансовому році [13].

Розрахунок цього індикатора відбувається в розрізі двох основних груп платників податків: осіб, що самостійно заповнюють податкові декларації та податкових агентів [4]. Оцінювання ПР у Сполученому Королівстві з персонального прибуткового податку відбувається «знизу вверх» і із застосуванням методів випадкових запитів, після чого формується випадкова вибірка із декларацій платників, що були повідомлені про необхідність подання декларацій [1, с. 144]. Водночас для розрахунку такого показника контролюючий орган використовує дані із власних джерел, як-от опитування, адміністративні й операційні дані, що були актуальні для періодів, які передують досліджуваному періоду (тобто дані за 2015-2016 податковий рік базуються на показниках попередніх років). При аудиті випадкової вибірки платників, не повною мірою задекларовані податки масштабуються до кількості всіх платників податків і саме ці дані використовують для оцінки ПР. Програмні продукти, що застосовують для формування випадкової вибірки, не ідентифікують усі декларації, у яких $є$ помилки, а також не вказують на весь масштаб ПР (з огляду на наявність випадків, коли немає інформації із третіх джерел, яку можуть використати для перевірки) [11]. 
У США ПР трактують як суму податкового зобов'язання, що не сплачена платниками податків вчасно. Він становив 450 млрд дол. США у 2006 р., але зріс і середнє значення у 2008-2010 рр. становило 458 млрд дол. США, тобто показник дотримання податкового законодавства знизився із 83,1\% до 81,7\% [16]. Тобто, у середньому у 2008-2010 pр. ПР з ПДФО у США становив 264 млрд дол. США, з яких найбільшу частку становило ПДФО від ведення бізнесу - 125 млрд дол. США [17].

У Канаді ПР розглядають як суму не сплачених вчасно податків, а також податків, що могли б потенційно бути сплачені із тіньової економіки, але про які взагалі немає відомостей у контролюючих органів. Характерною рисою канадської системи персонального прибуткового оподаткування $є$ загальність декларування доходів (близько 27 млн платників щорічно подають форму T1, що є аналогом декларації про майновий стан і доходи) та високий рівень слідування податковому законодавству, зокрема й за рахунок перевірки інформації від третіх осіб. Станом на 2014 р. ПР становив 8,7 млрд дол., тобто 6,4\% від надходжень у вигляді персонального прибуткового податку (при цьому ПР через невчасну сплату становив 2,2 млрд дол., тобто 1,6\% від надходжень у вигляді персонального прибуткового податку, а ПР, пов'язаний із тіньовою економікою, оцінений у 6,5 млрд дол. або 4,8\% від надходжень у вигляді персонального прибуткового податку та $0,3 \%$ від ВВП) [15].

ПР із персонального прибуткового податку в Канаді розраховується з використанням підходу «знизу вверх». Зокрема, за допомогою випадкових перевірок даних щодо репрезентативної вибірки Т1 декларацій, отримані дані екстраполюються на все населення, що зобов'язано подавати відповідні декларації до контролюючого органу. Контролюючі органи застосовують програму «випадкового аудиту» для оцінки не слідування податковому законодавству для малих та середніх підприємств, проте для оцінки слідування законодавства 3 персонального прибуткового податку не застосовують складну та ресурсно-затратну систему «випадкового аудиту» (де кожен із рівною ймовірністю може бути обраний до перевірки), а натомість використовують дані внутрішніх досліджень щодо зусиль із слідування податковому законодавству, які грунтуються на визначених ризиках. Таким чином, контролюючі органи фокусуються на високо ризиковій частині населення [15].

Значну роль у дотриманні високого рівня слідування податковому законодавсту $є$ й отрмання інформації про доходи від третіх осіб. Контролюючі органи Канади мають доступ до:

- форми T4, яку роботодавці надають працівникам із даними щодо виплачених доходів у вигляді заробітної плати, податків і також внесків на страхування зайнятості та пенсійне забезпечення, а також інші утримання;

- інформації від фінансових установи щодо внесків на зареєстровані пенсійні плани (Registered Retirement Savings Plans);

- форми Т4А(Р) щодо отриманих виплат за пенсійним забезпеченням;

- форми Т5, яка видається фінансовими установами щодо інвестиційного доходу, який отримали фізичні особи [15].

Окрім того, процеси співставлення інформації є автоматизованими, після подання звітності проходить автоматична перевірка даних, що позитивно впливає на адміністрування.

ПР тісно пов'язаний із рівнем тіньової економіки. Зростання ролі електронних розрахунків поступово стимулюватиме до збільшення транспарентності, зокрема, й самозайнятих осіб. Водночас дуже важливим $€$ звітування третіх осіб, про отримані доходи та проведені операції. Як наголошено в роботі Х. Клевена, у Данії дуже низький рівень ухилень від оподаткування, навіть самозайнятими особами, що пов'язано із високим рівнем використання інформації від третіх осіб (покриває майже $95 \%$ доходу) [10, c. 79-81].

Європейська Комісія розглядає показник «податковий розрив» як перспективний інструмент для оцінки необхідності вдосконалення податкової політики та адміністрування податків. Цей орган залучає зовнішніх дослідників для визначення ПР із ПДВ у державах-членах $Є С$, а МВФ надає підтримку ряду юрисдикцій при оцінці ПР. У контексті цього було прийнято рішення проаналізувати ПР із ПДВ у 2000-2012 рр. у державах-членах ЄС. 3 огляду на існування різних методологій оцінки ПР, було створено робочу групу (в рамках програми «Fiscalis 2020») для вивчення досвіду держав, у яких уже здійснюється оцінка ПР (Сполучене Королівство, Данія, Естонія, Італія, Нідерланди та Словаччина), обміну досвідом та ідентифікації найбільш сприятливої методології для конкретних умов. До підгрупи з вивчення методологій оцінки ПР із прямого оподаткування входять представники податкових служб Іспанії, Словаччини, Португалії, Польщі, Нідерландів, Литви, Латвії, Італії, Угорщини, Німеччини, Фінляндії, Чехії, Болгарії, Бельгії [7].

3 огляду на те, що в Україні не застосовують загальнообов'язкове декларування доходів, а кількість декларацій про майновий стан і доходи, що подається фізичними особами, є малою [2] та не репрезентативною для всього населення, а тому підхід оцінювання ПР «знизу вверх» не можливо з високою точністю застосувати в Україні (тим не менше, більш детальне вивчення декларацій про майновий стан і доходи та декларацій осіб, уповноважених на виконання функцій держави або місцевого самоврядуван- 
ня, може підвищити якість оцінювання). Натомість більш доцільно застосовувати підхід «зверху вниз» з використанням даних Державної служби статистики України щодо доходів домогосподарств. Також отримані дані потребуються суттєвого коригування на розмір наявної тіньової економіки, а саме нелегальної зайнятості.

Показник ПР у перспективі можливо на щорічній основі розраховувати і для України, але попередньо необхідно розробити методику, яка б враховувала та відображала вітчизняні реалії.

Висновки. Отже, ПР слугує цінним джерелом інформації про рівень добровільності сплати податків, зручності сервісів, що надаються платникам податків, ефективності заходів з адміністрування, що реалізуються контролюючими органами, а також рівня податкової культури загалом. Зменшення величини ПР, за умов стабільності податкового законодавства і незмінності методики його розрахунку, може бути свідченням ефективності роботи контролюючих органів. У 2018 р. в Україні було вперше проведено незалежну оцінку процесу адміністрування податків TADAT (the Tax Administration Diagnostic Assessment Tool). Згідно з результатами цієї діагностики одним із основних недоліків у роботі ДФС є брак систематичного аналізу ПР [3].

3 огляду на це, ми вважаємо, що саме за цим видом аналітичної роботи, що має бути лише створений в Україні на основі врахування кращого світового досвіду, криється один із головних напрямів удосконалення процесу прийняття рішень у сфері податкової політики держави та, як результат цього, ефективності функціонування системи оподаткування України взагалі.

\section{Література:}

1. Вдовиченко А. М., Зубрицький А. І. Податкові розриви: теорія та можливості імплементації в Україні. Економіка та держава. 2013. № 8. С. 17-21.

2. Задорожня Л. А. Звітні аспекти адміністрування податку на доходи фізичних осіб в Україні. Інвестиції: практика і досвід. 2017. № 15. С. 26-31.

3. Процеси адміністрування податків в Україні оцінили за методом TADAT. URL: https://goo.gl/kiEvhK (Last accessed: 25.05.2018).

4. Система ключових індикаторів результативності діяльності органів Міністерства доходів і зборів України: монографія / за заг. ред. А. М. Вдовиченка. Київ, Алерта. 2013. 336 с.

5. Фільо М. М. Податкові втрати та податкові розриви: можливості ідентифікації. Вісник Одеського національного університету імені I. I. Мечникова. 2014. Т. 19. Випуск 5-6. С. 115-120.

6. Australian tax gaps overview URL: https://goo.gl/SX8yfC (Last accessed: 25.05.2018).

7. F2020 FPG/041 - Tax Gap project group (E03260) URL: http://ec.europa.eu/transparency/regexpert/index. $\mathrm{cfm} ? \mathrm{do}=$ groupDetail.groupDetail\&/groupID=3260 (Last accessed: 25.05 .2018 ).

8. Gemmell N., Hasseldine J. The tax gap: a methodological review. Advances in Taxation. 2012. P. 203-231.

9. Hamilton S. Regulatory compliance, case selection and coverage - calculating compliance gaps. Journal of Tax Research. 2015. Vol. 13. № 2, P. 616-673.

10. Kleven H. How Can Scandinavians Tax So Much? Journal of Economic Perspectives. № 28. P. 77-98.

11. Measuring tax gaps 2017 edition. Tax gap estimates for 2015-16 URL: https://www.gov.uk/government/uploads/ system/uploads/attachment_data/file/655097/HMRC-measuring-tax-gaps-2017.pdf (Last accessed: 25.05.2018).

12. PAYG withholding gap URL: https://goo.gl/B43Jpg (Last accessed: 25.05.2018).

13. Superannuation guarantee gap URL: https://goo.gl/L9uX78 (Last accessed: 25.05.2018).

14. Tax administration 2015: Comparative Information on OECD and Other Advanced and Emerging Economies. OECD Publishing. 2015. P. 380.

15. Tax assured and tax gap for the federal personal income tax system URL: https://goo.gl/uEhHKK (Last accessed: 25.05.2018).

16. Tax Gap Estimates for Tax Years 2008-2010 URL: https://www.irs.gov/newsroom/the-tax-gap-0 (Last accessed: 25.05.2018).

17. Tax Gap Estimates for Tax Years 2008-2010: Overview URL: https://www.irs.gov/pub/newsroom/tax\%20 gap\%20estimates\%20for\%202008\%20through\%202010.pdf (Last accessed: 25.05.2018).

18. Warren N., McManus J.The Impact of Tax Gap on Future Tax Reforms. The Australian Economic Review. 2007. Vol. 40. № 2. P. 200-207. 